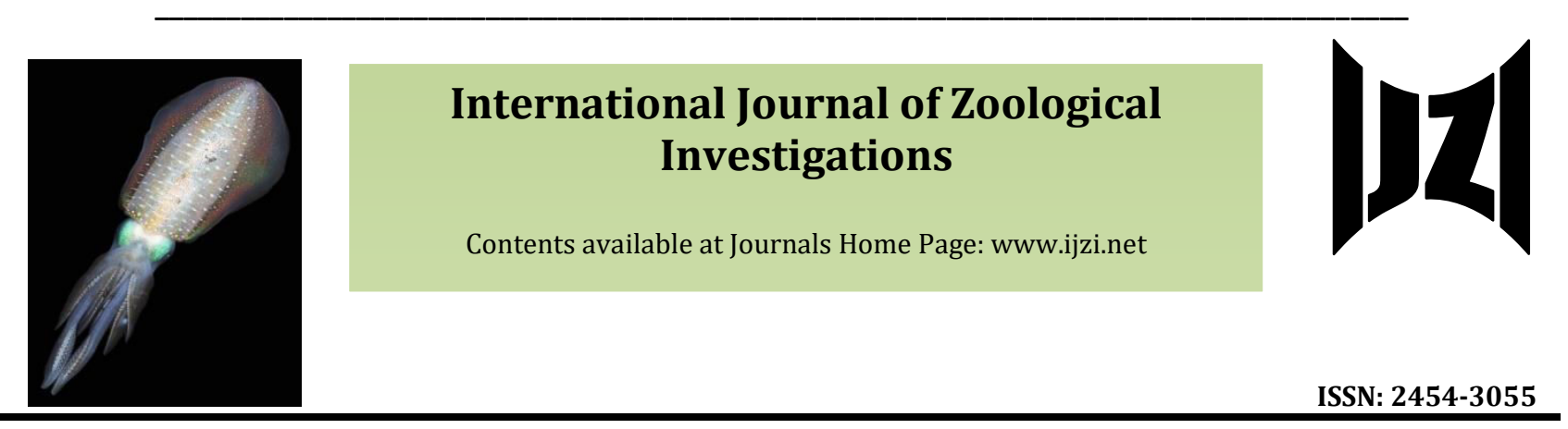

\title{
Preliminary Survey of Major Insect Pests of Rice (Oryza sativa L.) from Panvel, Navi Mumbai, India
}

\author{
Pawar Prabhakar R.*, Mhatre Ramesh P. and Supnekar Santosh P. \\ Mahatma Phule Arts, Science and Commerce College, Panvel, Raigad, Navi Mumbai 410206, India \\ *Corresponding Author
}

Received: 24th December, 2020

Accepted: $12^{\text {th }}$ February, 2021

Published online: $13^{\text {th }}$ February, 2021

https://doi.org/10.33745/ijzi.2021.v07i01.003

\begin{abstract}
A preliminary survey of major insect pests on rice was carried out during the Kharif season of 2020, from June 2020 to October 2020 in selected plots of rice around Panvel, Navi Mumbai, India. 16 species of insect pests representing 03 orders, 06 families and 15 genera were observed. Number of species of insect pests distributed in each family reveals that 09 species belongs to family Acrididae, 03 species to Erebidae and 1 species each to Crambidae, Nymphalidae, Libellulidae and Pyrgomorphidae. Family Acrididae shows the highest percent representation of species (56.25\%) followed by Erebidae (18.75\%) and Crambidae, Nymphalidae, Libellulidae and Pyrgomorphidae (6.25\%). Results of the preset study indicates that larval forms and adults of grasshoppers, dragon flies and bugs are the major insect pests of paddy at various growth stages. It is recommended that preventive measures like frequent dusting and spraying of insecticides and de-weeding of the crop will control the infestation by insect pests and will improve the yield of rice. Since no earlier reports are available, data presented here can be taken as a baseline data on major insect pests of rice in Panvel region, Navi Mumbai, India.
\end{abstract}

Keywords: Grass hopper, Insects, Navi Mumbai, Panvel, Pests, Rice

Citation: Pawar Prabhakar R., Mhatre Ramesh P. and Supnekar Santosh P.: Preliminary survey of major insect pests of rice (Oryza sativa L.) from Panvel, Navi Mumbai, India. Intern. J. Zool. Invest. 7 (1): 22-31, 2021. https://doi.org/10.33745/ijzi.2021.v07i01.003

\section{Introduction}

Rice (Oryza sativa Linnaeus, 1753) is staple food for more than two billion people in Asia and few hundred million in Africa and Latin America (Rohman et al., 2014; Saha et al., 2015; Maqsood et al., 2016; Qureshi et al.,
2018). The production of rice globally exhibited a fluctuating trend in the past few years. In 2014-15, the global production of rice was 479 million tonnes (Shinde, 2017). India is world's second largest rice producer 
and consumer next to China. India has 43.79 million hectares (ha) total area under rice with production of 109.70 million tonnes and productivity of $2494 \mathrm{~kg} / \mathrm{ha}$. In Maharashtra state, rice is cultivated over an area about 14.66 lakh/ha with production about 34.19 lakh tonnes having productivity 1.84 tonnes/ha. Major Rice growing districts in Maharashtra are Thane, Ratnagiri, Raigad, Sindhudurg, Kolhapur and Nashik (Patil et al., 2020).

Rice contributes to the major dietary energy for body. The nutrient content of rice contains proteins $(6.81 \mathrm{~g} / 100 \mathrm{~g})$, lipids $(0.55$ $\mathrm{g} / 100 \mathrm{~g})$, carbohydrates $(81.68 \mathrm{~g} / 100 \mathrm{~g})$, fiber $(2.8 \mathrm{~g} / 100 \mathrm{~g})$, energy (370 kcal) and water $(10.46 \mathrm{~g} / 100 \mathrm{~g})$ (Rohman et al., 2014). Rice can be used as a source of staple food, starch, rice bran, rice bran oil, flaked rice, puffed rice, parched rice and rice husk. Rice is excellent source of complex carbohydrates with low fat, low salt and no cholesterol. It is also a great source of proteins, vitamins and minerals (Chaudhari et al., 2018).

Medicinal values of rice and its products include inhibition of atherosclerotic plaque, reduced hyperglycemia and hyperlipidemia in diabetes, source of 8 essential amino acids, vitamins (B-complex and E-family) and excellent source of minerals ( $\mathrm{Fe}, \mathrm{Zn}, \mathrm{K}, \mathrm{Mn}, \mathrm{Cu}$, $\mathrm{Mg}, \mathrm{Ca}$ and P). Henderson et al. (2012) documented that dietary rice bran may exert beneficial effects against cancer of breast, lung, liver, colon and rectum. Rice consumption can be associated with risk of exposure to arsenic, pesticide residues and whitening agent, if the rice is contaminated with heavy metals, mycotoxins, insecticides and chlorine dioxide (Rohman et al., 2014). According to Hu et al. (2012) and Rohman et al. (2014), rice consumption is also related to the higher risk of diabetes mellitus.

Rice is cultivated in almost all the tropical, subtropical and temperate countries of the world. In India, one of the major constraints of rice production and low productivity is the occurrence of insect pests at various stages of the crop growth. The rice crop is subject to attack by more than 100 species of insects and 20 of them can cause economic damage (Patil et al., 2020). Insect pests damage rice crop from nursery sowing to transplanting up to maturity of crop. However the infestation of rice plant hoppers; stem borers; leaf folders are always a serious challenge to rice production (Venugoban and Ramanan, 2014; Maqsood et al., 2016; Bisen et al., 2019; Rath et al., 2020).

Rice is the second important crop of Maharashtra and the state rank $13^{\text {th }}$ in rice production in India. The Konkan region occupies about 4.01 lakh hectares area under rice with production of about 11.28 lakh tonnes with productivity around $2.81 \mathrm{t} / \mathrm{ha}$. Over a period of time in Konkan region, area under rice has declined. The decline in area under rice was more in Thane and Raigad districts. This could be attributed to fast urbanization, industrialization and shifting of agricultural land to non-agricultural uses in these districts (Shinde, 2017).

The Konkan region of Maharashtra (Thane and Raigad District) has typical lateritic soils. Forests of semi-deciduous and evergreen trees have flourished in many parts, but the forest cover is now fast diminishing, precipitating soil erosion. The major crops grown are rice, finger millets, small millets during Kharif season and cow pea, red gram, green gram, horse gram and dolichos bean in 
Rabi season. While in summer, groundnut and some vegetables are grown by irrigated farmers. The pest attack, particularly Yellow Stem Borer became more of an issue than it had ever been for many farmers (Pionetti, 1997).

Coastal environment of Panvel has been under considerable stress since the ongoing construction of Navi-Mumbai International Airport (NMIA) by the City and Industrial Development Corporation (CIDCO). Construction of NMIA has resulted into deforestation, encroachment, reclamation and urbanization in the study area. It has affected the livelihood of local fishermen and coastal community along with ecology of fauna from Panvel, Navi Mumbai (Pawar et al., 2019 a, b, 2020 a b, c).

Literature review suggests that no information is available on species composition of insect pests of rice from Panvel, Navi Mumbai, India. Hence, the present study was undertaken to assess the species composition of major insect pests of Rice (Oryza sativa L.) from Panvel, Navi Mumbai, India.

\section{Materials and Methods}

\section{Study Area}

Navi Mumbai is basically a satellite township on the west shore of Maharashtra, India. It was made in 1971 to be another urban township of Mumbai by Government of Maharashtra. As per Census India 2011, it had a population of 1,119,477. Panvel is located in Raigad district of Maharashtra in Konkan region and is a node of Navi Mumbai city.

Geographically, Panvel (1859'19.61" N $73^{\circ} 06^{\prime} 36.47^{\prime \prime}$ E) is located on the Western Ghats range at an elevation of about $11 \mathrm{~m}$ above sea level and has tropical climate with most months of the year are marked by significant rainfall (Fig. 1). The average annual temperature in Panvel is $27.0 \mathrm{C}$ with rainfall of about $3267 \mathrm{~mm}$ (128.6 inch) and average annual percentage of humidity is $75.0 \%$. Panvel has moderate air quality index and it may cause breathing discomfort to people with lung disease such as asthma, and discomfort to people with heart disease, children and older adults.

Panvel is the most populated city (population of 1,80,464; Census India 2011) in Raigad district in Maharashtra, India. Panvel is a highly populated city due to its closeness to Mumbai. It is located in the Mumbai Metropolitan Region on the banks of Panvel Creek. Kalundre river flows across the city in the south-west region and opens up into Panvel creek.

\section{Study Location}

The present study on preliminary survey of major insect pests on rice was carried out during the Kharif season of 2020, from June 2020 to October 2020. Selected plots of rice were visited during dawn and dusk hours, once in each week and 4 hours were spent at each site at both times.

The study sites were regularly surveyed for seasonal incidence of major insect pests on rice and the pest population was recorded. Insect pests were recorded on rice at various growth stages and from initiation of insect pest infestation up to maturity. Data on insect pests was collected by observations with naked eyes and with the aid of magnifying lens and were photographed using Cannon 1100 D Zoom camera. For correct identification of insect pests field guide of Shepard et al. (1995) was followed. 


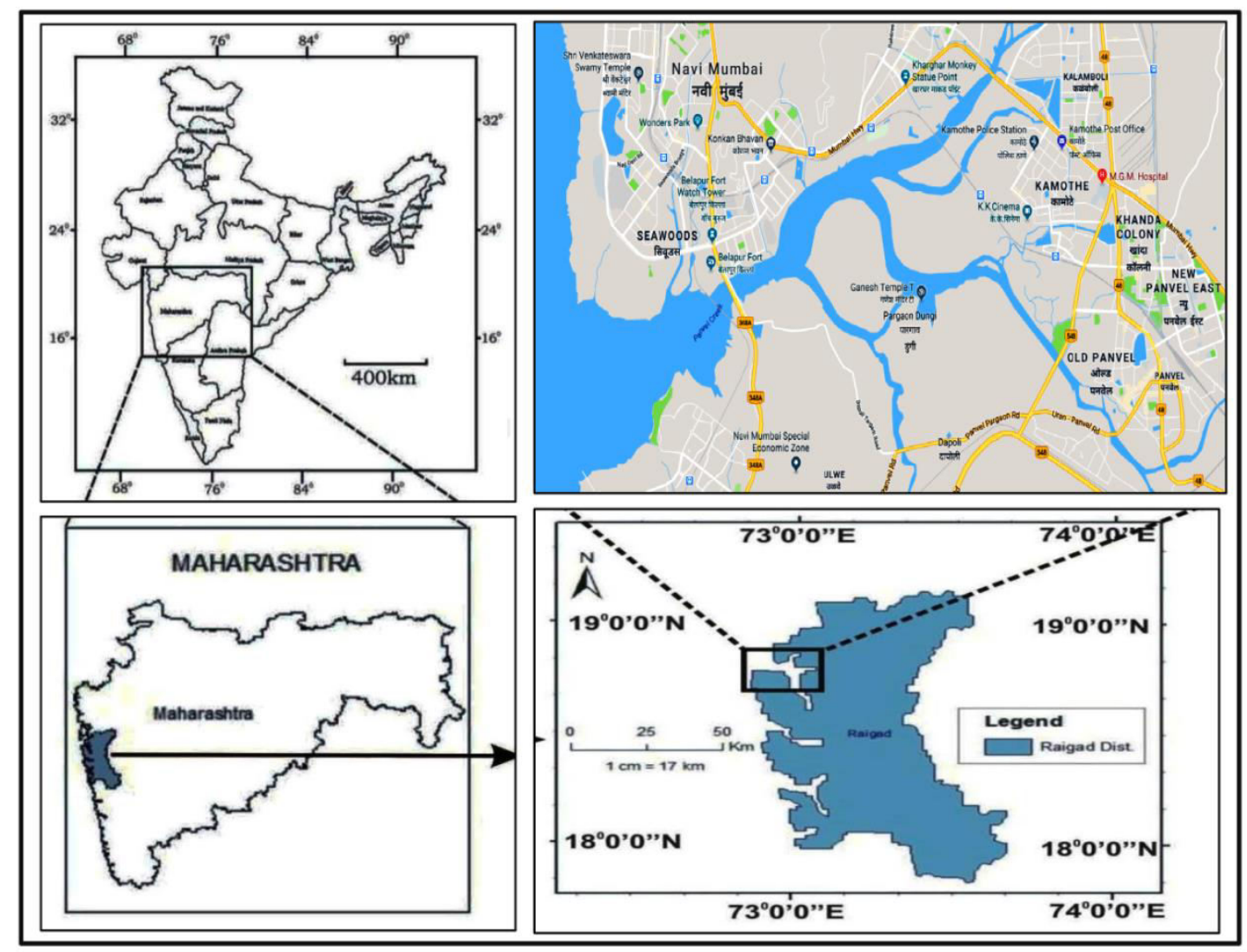

Fig. 1: Location map of study area representing Panvel creek

\section{Results and Discussion}

Varied diversity of insect pests with 16 species representing 03 orders, 06 families and 15 genera were observed (Tables 1, 2; Figs. 2, 3). Number of species of insect pests distributed in each family reveals that 09 species belongs to family Acrididae, 03 species to Erebidae and 1 species each to Crambidae, Nymphalidae, Libellulidae and Pyrgomorphidae. Family Acrididae shows the highest percentage representation of species (56.25\%) followed by Erebidae (18.75\%) and Crambidae, Nymphalidae, Libellulidae and Pyrgomorphidae (6.25\%) (Table 2). Results of the present study indicates that larval forms and adults of grasshoppers, dragon flies and bugs are the major insect pests of paddy at various growth stages.
Various major insect pests of paddy observed during present study includes:

(i) Neurothemis tullia: It is a conspicuous species found in paddy fields and is very common along irrigation canals in paddy fields. It is found throughout the year, however, peak abundance is noted during July to September.

(ii) Catantops pinguis innotabilis: It is very common pest of paddy with maximum population in October.

(iii) Poekilocerus pictus: A most colourful grasshopper, commonly known as Painted Grasshopper and are reported during postmonsoon at the maturity of paddy crops. They generally feeds on Calotropis gigantia but also occasionally causes considerable damage by 
Table 1: Preliminary checklist of major insect pests on rice from Panvel, Navi Mumbai

\begin{tabular}{|c|c|c|c|c|}
\hline No. & Order & Family & Scientific Name & Common name \\
\hline 1 & Lepidoptera & Crambidae & $\begin{array}{c}\text { Cnaphalocrocis medinalis } \\
\text { (Guenee, 1854) }\end{array}$ & Rice leaf roller \\
\hline 2 & Lepidoptera & Erebidae & Euproctis virguncula (Walker, 1855) & Eupterotid hairy caterpillar \\
\hline 3 & Lepidoptera & Erebidae & Naranga aenescens (Moore, 1881) & $\begin{array}{l}\text { Rice green caterpillar/ } \\
\text { Rice green semilooper }\end{array}$ \\
\hline 4 & Lepidoptera & Erebidae & Psalis pennatula (Fabricius, 1793) & Yellow hairy caterpillar \\
\hline 5 & Lepidoptera & Nymphalidae & $\begin{array}{c}\text { Melanitis leda ismene } \\
\text { (Linnaeus, 1758) }\end{array}$ & $\begin{array}{c}\text { Rice butterfly } \\
\text { (Common evening brown) }\end{array}$ \\
\hline 6 & Odonata & Libellulidae & Neurothemis tullia (Drury, 1773) & Pied Paddy Skimmer \\
\hline 7 & Orthoptera & Acrididae & Acrida exaltata (Walker, 1859) & \\
\hline 8 & Orthoptera & Acrididae & Acrida gigantea (Herbst, 1786) & \\
\hline 9 & Orthoptera & Acrididae & $\begin{array}{c}\text { Aiolopus thalassinus tamulus } \\
\text { (Fabricius, 1798) }\end{array}$ & \\
\hline 10 & Orthoptera & Acrididae & $\begin{array}{c}\text { Catantops pinguis innotabilis } \\
\text { (Dirsh, 1956) }\end{array}$ & \\
\hline 11 & Orthoptera & Acrididae & $\begin{array}{c}\text { Diabolocatantops innotabilis } \\
\text { (Walker, 1870) }\end{array}$ & Devil grasshopper \\
\hline 12 & Orthoptera & Acrididae & Hieroglyphus banian (Fabricius, 1798) & Rice grasshopper \\
\hline 13 & Orthoptera & Acrididae & Patanga succincta (Johannson, 1763) & Bombay locust \\
\hline 14 & Orthoptera & Acrididae & $\begin{array}{c}\text { Stenocatantops splendens } \\
\text { (Thunberg, 1815) }\end{array}$ & \\
\hline 15 & Orthoptera & Acrididae & $\begin{array}{c}\text { Xenocatantops humilis } \\
\text { (Serville, 1838) }\end{array}$ & \\
\hline 16 & Orthoptera & Pyrgomorphidae & Poekilocerus pictus (Fabricius, 1775) & Painted grasshopper \\
\hline
\end{tabular}


Table 2: Per cent representation of families, order, genera and species of major insect pests on rice from Panvel, Navi Mumbai

\begin{tabular}{|c|c|c|c|c|c|}
\hline Sr. No. & Order & Family & Genera & Species & $\begin{array}{c}\% \\
\text { Representation }\end{array}$ \\
\hline 1 & Lepidoptera & Crambidae & 01 & 01 & 6.25 \\
\hline 2 & & Erebidae & 03 & 03 & 18.75 \\
\hline 3 & & Nymphalidae & 01 & 01 & 6.25 \\
\hline 4 & Odonata & Libellulidae & 01 & 01 & 6.25 \\
\hline 5 & Orthoptera & Acrididae & 08 & 09 & 56.25 \\
\hline 6 & & Pyrgomorphidae & 01 & 01 & 6.25 \\
\hline Total & 03 & 06 & 15 & 16 & 100 \\
\hline
\end{tabular}

feeding on young plants of paddy. Adults are capable of good flight and can swarm if conditions are favourable.

(iv) Aiolopus thalassinus tamulus: It is a common pest in paddy fields. A medium sized grasshopper commonly associated with grass and attached on cultivated field like paddy. Both the larval and adult forms are serious pests of the paddy crop at young and mature stages.

(v) Acrida exaltata: This species is associated with grass. Nymphs and adults occur almost throughout the year. They cause serious damage to paddy at all growth stages of rice. Maximum population is observed in the month of September and minimum in February.

(vi) Acrida gigantea: This species is associated with tall grass and is recorded from paddy fields near roadsides and water channels having tall grasses. (vii) Xenocatantops humilis: This species is generally inhabitant of forest. Heavy infestation of this species has been recorded in paddy fields during maturity. Adults are almost found in every month. Nymphs are found in groups under the leaves.

(viii) Diabolocatantops innotabilis: It causes minor damage to Rice. Maximum population is noted in the month of October. Both adults and nymphs are found from March to first week of December.

(ix) Stenocatantops splendens: It is a serious pest recorded in rice field and also attacks the members of the family Cucurbitacea.

(x) Patanga succincta: Popularly known as Mumbai locust and is a major pest of rice in swarming phase. Adults and nymphs feed on shoot and leaves of paddy. Adults are very active and can travel long distances.

(xi) Hieroglyphus banian: Major pest of paddy and it is commonly known as rice grasshopper. The hopper hatches at the end of 

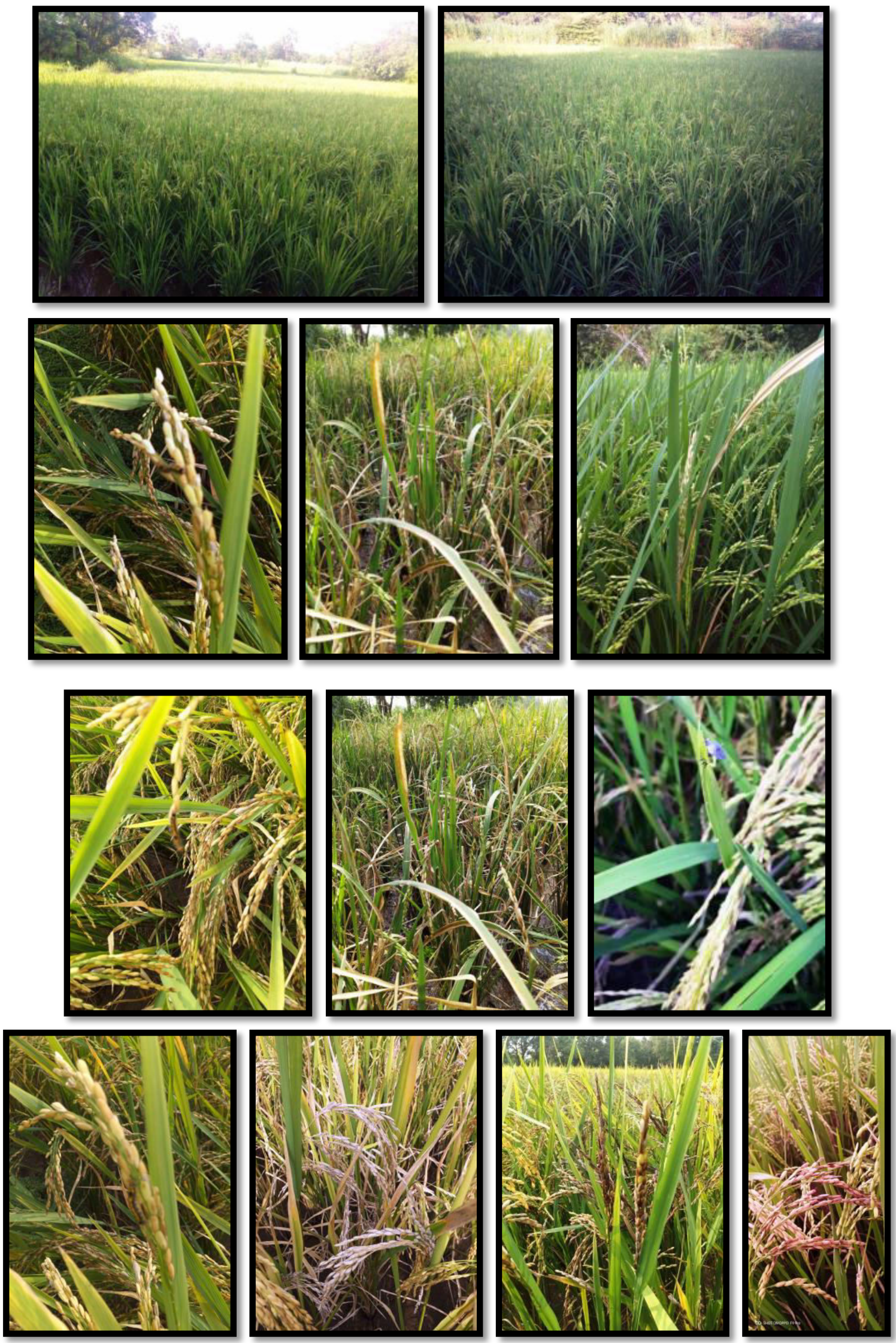

Fig. 2: Paddy crop infested with insect pests 


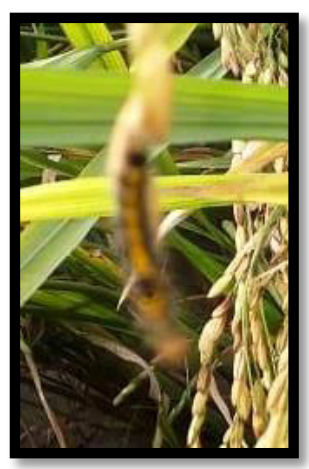

Larva of $C$. medinalis

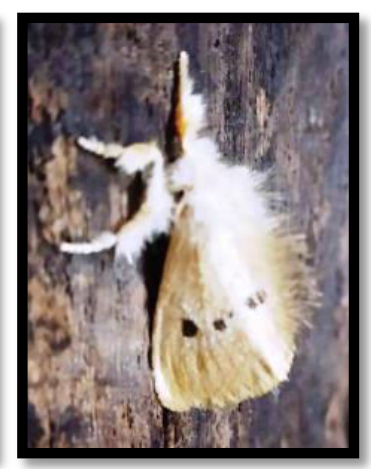

Euproctis virguncula

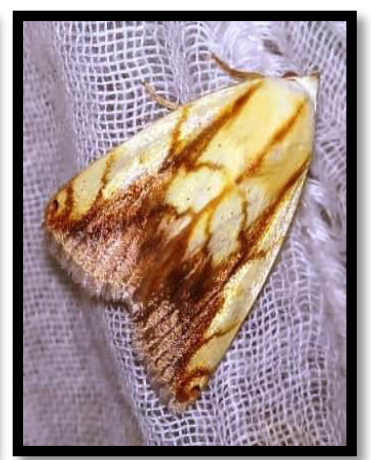

Naranga aenescens

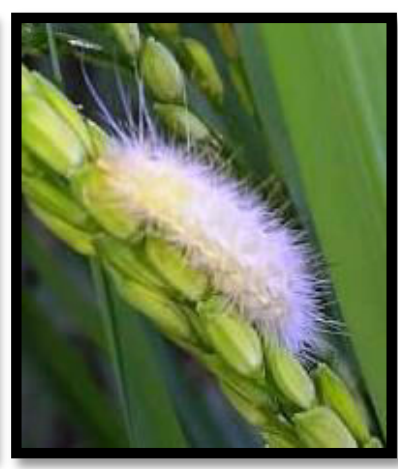

Psalis pennatula

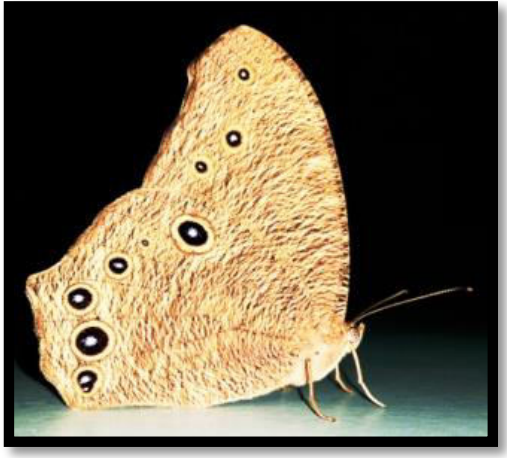

Melanitis leda ismene

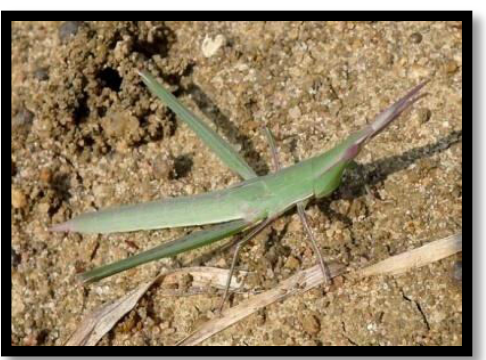

Acrida gigantea

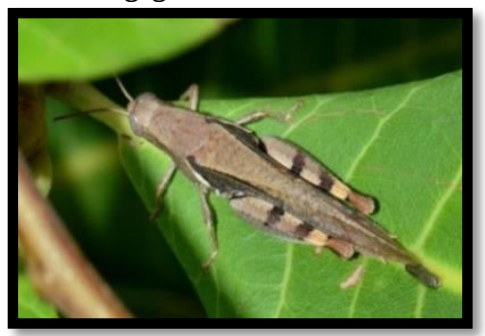

Diabolocatantops innotabilis

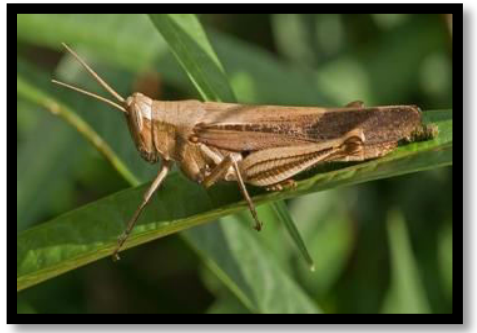

Stenocatantops splendens

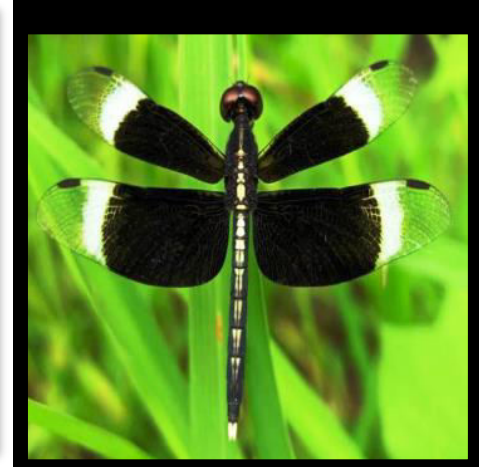

Neurothemis tullia

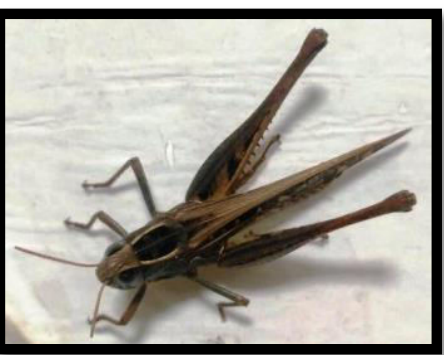

Aiolopus thalassinus tamulus

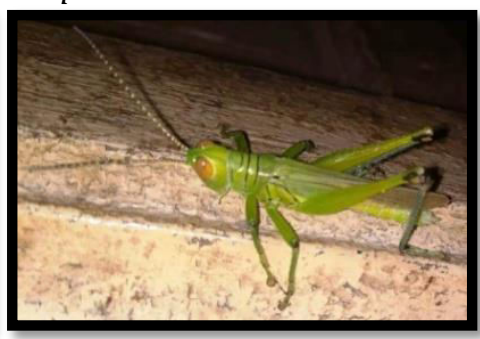

Hieroglyphus banian

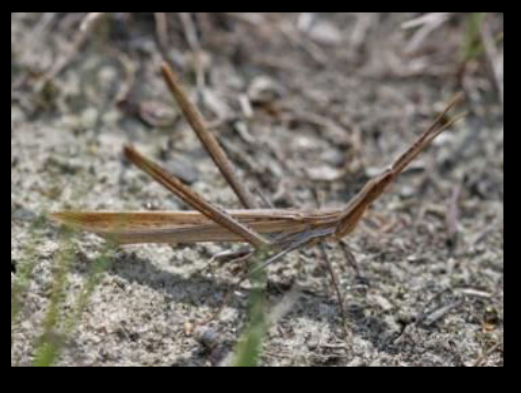

Acrida exaltata

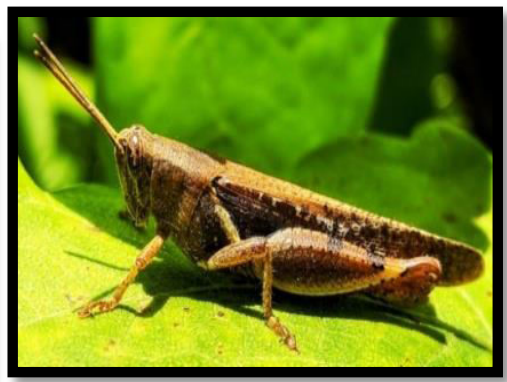

Catantops pinguis innotabilis

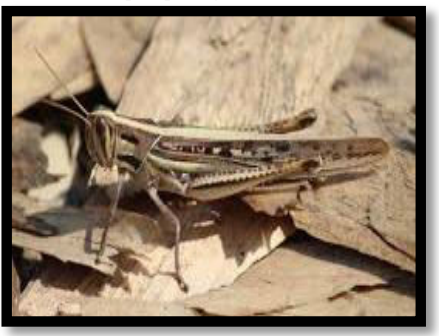

Patanga succincta

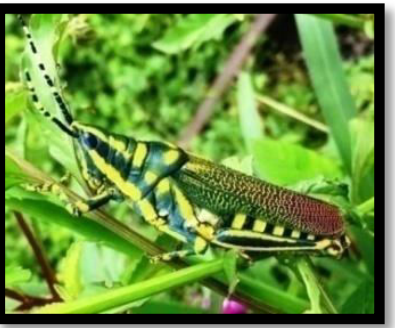

Poekilocerus pictus

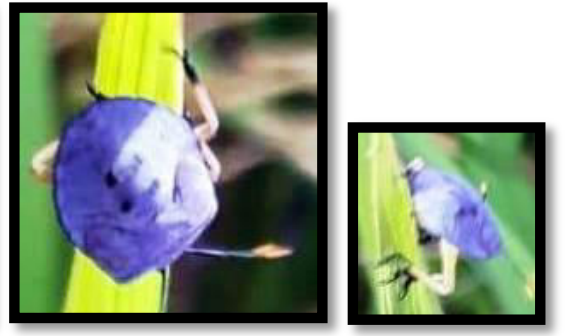

Unidentified Violet bugs

Fig. 3: Insect pests of paddy recorded in and around Panvel, Navi Mumbai 
July to August and becomes adult in September to October. The population reaches its peak at the end of October when the paddy is fully matured.

(xii) Violet coloured bugs: Unidentified violet coloured bugs were reported as a serious pest of rice at early growing stage, from June to July. Adults were observed on the lower side of the leaves and heavy infestation leads to the drying of the leaves.

Results of the study are in agreement with the findings on species diversity of insect pests of rice by Maqsood et al. (2016) from Sialkot District of Punjab, Pakistan; Bisen et al. (2019) from Balaghat District Madhya Pradesh; Patil et al. (2020) from the Agricultural Research Station Farm, Igatpuri, Maharashtra and a Review of Biodiversity of insect pests of rice in India by Rath et al. (2020).

At present, due to over-exploitation of natural resources for ongoing construction of Navi Mumbai International Airport, deforestation, intense industrialization and urbanization, coastal pollution will affect the yield and crop pattern around Panvel. Therefore, data presented in this paper can be taken as a base line data for future study.

\section{Conclusion}

The study shows that, rice crop in areas around Panvel is infested by diverse species of grasshoppers, dragonflies and caterpillars of many insect species. The insect pests are affecting all the growth stages of rice, from early seedling stage up to maturity. It is noted that frequency of insect pests is high in July and August and increases with increase in precipitation. It is recommended that preventive measures like frequent dusting and spraying of insecticides and de-weeding of the crop will control the infestation by insect pests and will improve the yield of rice. Since no earlier reports are available, data presented here can be taken as a baseline data on major insect pests of rice in Panvel region, Navi Mumbai, India.

\section{Acknowledgement}

Encouragement and support provided by Dr. Ganesh A. Thakur, Principal, Mahatma Phule Arts, Science and Commerce College, Panvel, Raigad, Navi Mumbai is gratefully acknowledged. Authors are thankful to The Head, Department of Zoology, Mahatma Phule Arts, Science and Commerce College, Panvel, Raigad, Navi Mumbai for providing necessary facilities for the present study.

\section{References}

Bisen D, Bisen U and Sharad B. (2019) Studies on major insect pests of rice crop (Oryza sativa) at Balaghat district of Madhya Pradesh. J Entomology Zool Studies 7: 625-629.

Chaudhari PR, Nishesh T, Singh L, Tandon A and Sharma D. (2018) Rice nutritional and medicinal properties: A review article. J Pharma Phytochem. 7: 150-156.

Henderson AJ, Ollila CA, Kumar A, Borresen EC, Raina K, Agarwal R and Ryan EP. (2012) Chemo-preventive properties of dietary rice bran: Current status and future prospects. Adv Nut. 3: 643-653.

$\mathrm{Hu}$ EA, Malik V and Sun Q. (2012) White rice consumption and risk of type 2 diabetes: metaanalysis and systematic review. BMJ. 344: e1454. doi: 10.1136/bmj.e1454.

Maqsood A, Zuhaib A, Talfoor H, Muhammad L, Muzzammil H, Mazher FI, Muhammad JS, Muhammad F, Allah RS and Muhammad AA. (2016) Entomological survey of pests of rice nursery and crop in district Sialkot Punjab-Pakistan. Int. J. Adv. Res. Biol. Sci. 3: 159-164.

Patil SD, Kusalkar DV, Patil HM and Bhoite KD. (2020) Seasonal incidence of insect pests on rice and impact of various abiotic factors on their incidence. J Pharma Phytochem. 9: 1869-1872. 
Pawar Prabhakar R, Atul JP, Anil GR, Namdeo BP and Shreya RP. (2019 a) Monitoring of anthropogenic threats to mangrove ecosystem of Panvel Creek, Navi Mumbai, India. Res Chron. 7: 74-84.

Pawar Prabhakar R, Meshram LN, Udawant SM and Rauphunnisa FI. (2019 b) Assessment of coastal pollution using faunal composition of macrobenthos from Panvel Creek, Navi Mumbai, West Coast of India. Res Chron. 7: 28-38.

Pawar Prabhakar R., Rokade AG, Supnekar SP, Meshram LN and Pawar NB. (2020 a) Anthropogenic impact on species diversity and distribution of birds from coastal region of Panvel, Navi Mumbai, India. Intern. J. Zool. Invest. 6: 260-271.

Pawar Prabhakar R, Rokade AG, Supnekar SP, Meshram LN, Pawar NB and Gavhane UV. (2020 b) Diversity and distribution of snakes in adjoining areas of Panvel, Navi Mumbai, West Coast of India Intern. J. Zool. Invest. 6: 289-300.

Pawar Prabhakar R, Rokade AG, Supnekar SP, Meshram LN and Pawar NB. (2020 c). Preliminary data on species diversity of amphibians and reptiles (excluding snakes) from Panvel, Navi Mumbai, India. Asian J Adv Res. 4: 18-30.

Pionetti C. (1997) Rice cultivation in a tribal district of Maharashtra: Genetic erosion and economic vulnerability. 09/1997. http://base.d-p-h.info/en/ fiches/premierdph/fiche-premierdph-4112.html
Qureshi SP, Belurkar Y, Mehar P, Kodape D and Selokar M. (2018) Study of diseases on rice (Oryza sativa) in major growing field of Bhandara District. Intern J Agricul Sci. 10: 5573-5575.

Rath PC, Bose LK, Subudhi HN, Lenka S and Jambhulkar NN. (2020) Biodiversity of insect pests of rice in India. Intern J Chem Studies 8: 2998-3002.

Rohman A, Siti H, Mirza H and Dwi LS. (2014) Rice in health and nutrition. Intern Food Res J. 21: 13-24.

Saha S, Garg R, Arunava B and Rai AB. (2015) Bacterial diseases of rice: An overview. J Pure Appl Microbio. 9: 725-736.

Shepard BM, Banion AT and Litsinger JA. (1995) Ricefeeding insects of tropical Asia. Intern Rice Res Inst, Manila 1099, Philippines.

Shinde AA. (2017) Rice production in Konkan region An economic analysis. Ph. D. Thesis submitted to Dr. Balasaheb Sawant Konkan Krishi Vidyapeeth Dapoli, Ratnagiri, Maharashtra, pp. 206.

Venugoban K and Amirthalingam R. (2014) Image classification of paddy field insect pests using gradient-based features. Intern J Machine Learn Comput. 4:1-5. 